\title{
Empathy Levels of Dental Students of Central America and the Caribbean
}

\author{
Víctor Patricio Díaz-Narváez ${ }^{1,2 *}$, Ana María Erazo Coronado33, Jorge Luis Bilbao ${ }^{4}$, \\ Farith González ${ }^{5}$, Mariela Padilla', Madeline Howard ${ }^{7}$, Guadalupe Silva ${ }^{8}$, Joel Arboleda ${ }^{8}$, \\ Mirian Bullen', Robert Utsman6, Elizabeth Fajardo ${ }^{10}$, Luz Marina Alonso ${ }^{11}$, \\ Marcos Cervantes ${ }^{12}$ \\ ${ }^{1}$ Facultad de Odontología, Universidad San Sebastián, Santiago, Chile \\ ${ }^{2}$ Universidad Autónoma de Chile, Santiago, Chile \\ ${ }^{3}$ Universidad Metropolitana, Barranquilla, Colombia \\ ${ }^{4}$ Facultad de Medicina, Universidad Libre Seccional Barranquilla y Fundación Universitaria San Martín Sede \\ Puerto Colombia, Barranquilla, Colombia \\ ${ }^{5}$ Facultad de Odontología, Universidad de Cartagena, Cartagena, Colombia \\ ${ }^{6}$ Universidad Latinoamericana de Ciencia y Tecnología, San José, Costa Rica \\ ${ }^{7}$ Facultad de Odontología, Universidad de Costa Rica, San José, Costa Rica \\ ${ }^{8}$ Universidad Central del Este, San Pedro de Macorís, República Dominicana \\ ${ }^{9}$ Facultad de Odontología, Universidad de Panamá, Ciudad de Panamá, República de Panamá \\ ${ }^{10}$ Faculty of Health Sciences, Universidad del Tolima, Ibagué, Colombia \\ ${ }^{11}$ División de Salud, Universidad del Norte, Barranquilla, Colombia \\ ${ }^{12}$ Facultad de Ciencias Sociales, Universidad del Norte, Barranquilla, Colombia \\ Email: victor.diaz@uss.cl, amec1708@gmail.com, jbilbao55@hotmail.com, fgonzalezm1@unicartagena.edu.co, \\ mpadilla@ulacit.ac.cr, mhowarducr@gmail.com, guadalupesilva1@gmail.com, Jarboleda@uce.edu.do, \\ ladymi516@yahoo.com, rutsmana282@ulacit.ed.cr, efajardo@ut.edu.co, Imalonso@uninorte.edu.co, \\ marcos.cervantes@gmail.com
}

Received 9 November 2015; accepted 18 December 2015; published 21 December 2015

Copyright (C 2015 by authors and Scientific Research Publishing Inc.

This work is licensed under the Creative Commons Attribution International License (CC BY).

http://creativecommons.org/licenses/by/4.0/

(c) (i) Open Access

\section{Abstract}

Objective: The aim of this study is to check whether there are differences in the distribution of empathy levels in dental students from nine faculties of dentistry Colombia, Panama, Costa Rica and Dominican Republic. Methods: The levels of empathy and matrices of empathy construct matrices are estimated dental students by using the Jefferson Scale of Physician Empathy, the Spanish version for students (S version) culturally validated in Colombia, Panama, Costa Rica and Dominican Republic measured by arbitrator criteria. Cronbach $\alpha$ is estimated. Data of empathic orientation of the studied factors between faculties are analyzed and compared by ANOVA and Duncan

*Corresponding author.

How to cite this paper: Díaz-Narváez, V.P., Coronado, A.M.E., Bilbao, J.L., González, F., Padilla, M., Howard, M., Silva, G., Arboleda, J., Bullen, M., Utsman, R., Fajardo, E., Alonso, L.M. and Cervantes, M. (2015) Empathy Levels of Dental Students of Central America and the Caribbean. Health, 7, 1678-1686. http://dx.doi.org/10.4236/health.2015.712182 
test and matrices of empathy construct using discriminant analysis. Results: We find that there are differences in levels of empathy between universities, courses, gender and interaction between the Dental Faculty (University) and Course. The comparison between matrices shows unexplained variances and differences observed between the levels of empathy in student populations. Conclusions: Variability in empathy is observed in the studied factors and among student populations. The variability is an empirical finding, but is not possible in this work, to explain why.

\section{Keywords}

Empathy, Jefferson Scale of Physician Empathy (JSPE), Levels of Empathy

\section{Introduction}

Empathy is an attribute that contributes positively [1]-[5] in the process of patient care by the health professional. Empathy should also be given attention in the process of formation of these health professionals [6]. Empathy is defined based on three dimensions: a) to put into perspective, b) care with compassion and c) the ability to "step into the shoes of the patient" [7] [8]; as a result, they are involved in complex cognitive and emotional processes.

The empirical evidence observed in several studies of faculties of various health careers appears to be contradictory in relation to the examination of, at least, two factors: year (academic year) and gender [1]-[5] [7][10]. The possible explanation for this diversity of results may be due to the varying components of empathy maybe, in turn, influenced by other variables that affect the structure of the components of empathy [5]. According to Silva et al. [11], these differences open new areas of investigation concerning the possible socio-cultural implications that can influence the empathy. However, there are no studies comparing the empathy between different higher education institutions within a country and between countries. The existence of such differences may constitute empirical evidence of socio-cultural factors that affect the structuring of empathy in ontogenetic processes in the subjects. The aim of this study is to test whether there are differences in levels of empathy among student populations of nine dental schools from four countries of Central America and the Caribbean.

\section{Materials and Methods}

This study, an exploratory, cross-sectional and ex post facto cause-effect [12], (was approved by the Ethics Committee of Research, University of Development and German Clinic with approval of code CAS-UDD approval: 2011-64 in Santiago de Chile). It addresses students composed by levels from first through fifth years of Dental School, from the Faculty of Dentistry of Metropolitan University (Erazo et al.) [13] and San Martin de Barranquilla (Bilbao et al.) [3], University of Magdalena (sent to publish) and University of Cartagena (sent to publish) of the Republic of Colombia; Universidad Latina (sent to publish) and University of Panama (sent by publish) of the Republic of Panama; Latin University of Science and Technology (Sanchez et al.) [14] and the University of Costa Rica (Howard et al.) [15] of the Republic of Costa Rica, and the Universidad Central del Este (Silva et al.) [11] of the Dominican Republic. Data collection was conducted from June to August 2012, simultaneously at designated schools. The sample was comprised of those subjects who could be evaluated on the day the instrument was applied. All students, upon the application of the scale, were attending the last part of the first semester of each course. Participants from each of the samples were applied the Jefferson Scale of Physician Empathy (JSPE), the Spanish version for students (S version), and culturally appropriate in each of the countries studied by Committee Criteria [7] [16] [17]. There were no exclusion criteria, since the object was to evaluate the variable of interest of the majority of students. Consistent with referred to above, a single anonymous and confidential measurement (after signing informed consent), performed by a neutral operator, was first applied to students of fourth year classes. In the case of fifth year students, the instrument was administered on a visit to the clinical setting, with the same indications previously mentioned.

\section{Statistical Methods}

The data were subjected to a Cronbach $\alpha$ (reliability by internal consistency) [18]-[20] and Cronbach $\alpha$ based on 
established elements. Subsequently, it estimated with Cronbach $\alpha$ that removing an item (question applied instrument) for each estimate, in order to verify the explanatory role of each question.

The summation score of raw data of empathy levels obtained were initially subjected to an Shapiro-Wilk normality test [21] and Levene test of homoscedasticity [22] on the three factors studied: University (Faculty), Course (Academic Year) and Gender. The descriptive statistics were estimated; arithmetic mean and standard deviation. The comparison of means among the factors within the levels of the main factors and the interactions between the main factors were performed using a general linear model and Duncan test for unbalanced data [12]. Observed power (1- $\beta)$ and the effect size $(\eta 2)$ [12] [23] were evaluated. Subsequently, a discriminant analysis was performed. The $\lambda$ statistic of Wilks [24] was used in order to measure the proportion of the total variance of the discriminant scores not explained by differences in the factors examined. To test whether the variance and covariance matrices of each University (School of Dentistry) come from or not the same population, Box's M test [24] [25] was used. Data were analyzed using the SPSS 20.0 statistical program. The level of significance was set at $\alpha \leq 0.05$ and $\beta \leq 0.20$ in all cases.

\section{Results}

The general value of Cronbach $\alpha$ was 0.775 and evidence of internal consistency can be characterized as good and the value of this statistic, based on established elements, resulted similar to the non-typified (0.782), all of which show that the variances are similar between elements [25] [26]. When the Cronbach $\alpha$ values were eliminated they fluctuated between 0.752 - 0.784 , all of which indicates that all elements are providing some degree of explanation of the construct studied. The statistic F = 6363.07; of a Hotelling T2 test, was highly significant $(p<0.0005)$, and shows that the means of the elements are distributed differently and indicates that the questions, possibly associated with some dimensions, are contributing in different ways to the explanation of the construct. All this, in general, shows that the scale is reliable in the data analyzed in this study.

The application of a three-factor model allowed to observe that the factors "University", "Course", Gender and, finally, "University" in interaction with the factor "Course" (University ${ }^{*}$ Course), were highly significant $(p<0.0005)$, which indicates that there are differences between the universities studied, between courses, between gender and between courses of different universities. However, the $\eta 2$ statistic, which indicates the magnitude of the effect size, is small $(0.104,0.009,0.007$ and 0.061 respectively). The observed values of the power of the test was 1.00; $0.903 ; 0.937$ and 1.00 respectively; all of which show that there is low risk of committing a Type II error. The R2 value was 0.217 uncorrected and corrected 0,177; which show that the model does not explain all the variation, but also shows the existence of other factors (other than those studied) that are influencing the determination of the values of the observed levels of empathy.

In Table 1, the mean values of the variable levels of empathy in every University studied are presented. In Table 2, the results of applying the Duncan test are presented. It is noted that four groups are formed. The first consists of the means of the University of Magdalena (Colombia), that was significantly different $(p<0.05)$ from the means of the Universities of Metropolitan and San Martin (Colombia) and Central del Este (Dominican Republic), which form a second group and, among them, there are no significant differences ( $p>0.05)$. Later a third group was composed of the means of the Universities America (Panama), ULACIT of Costa Rica, Cartagena (Colombia) and the University of Panama, among which there are no significant differences $(p>0.05)$. Finally, a fourth group was formed, only consisting of the means of the University of Costa Rica, which differed significantly $(p<0.05)$ of all previously formed groups.

Table 3 shows the mean results of the factor "Course". It is noted that two groups are formed, which differ significantly among them $(p<0.05)$.The first consists of the average of the "first year"; while the second group consists of the rest of the means of which between them there are no significant differences $(p>0.05)$. Regarding the "gender" factor, an average of 104.265 for the female gender (typical error $=0.446$; confidence interval with a Lower Limit $=103.351$ and Upper Limit $=105.179$ ) and, for males, the average was 101.446 (typical error $=0.79$; confidence interval Lower Limit $=99.517$ and Upper Limit $=102.615$ ), with significant differences $(p<0.05)$ between them. In Table 4, the results of the estimation of means between the University and Course factors (University ${ }^{*}$ Course) are presented.

The comparison between the complete data arrays of the instruments applied permit the estimation of the Box M statistic (3947.847), which was highly significant $(p<0.005)$; indicating that the covariance matrices between 
Table 1. Results of the estimation of mean, standard error and confidence interval of empathic orientation in each of the Dental University studied.

\begin{tabular}{cccc}
\hline Dental University & Median & Standard Error & \multicolumn{2}{c}{ Confidence Interval 95\% } \\
\cline { 3 - 4 } Universidad Latina de Panamá & 102.637 & 2.312 & Lower Limit \\
Universidad de Cartagena (Colombia) & 105.525 & 0.794 & 98.102 \\
Universidad de Magdalena (Colombia) & 92.490 & 1.098 & 103.968 \\
Universidad Metropolitana (Colombia) & 100.061 & 1.224 & 90.336 \\
Universidad Central del Este (Dominicana) & 101.724 & 1.120 & 97.659 \\
ULACIT de Costa Rica & 103.468 & 1.179 & 99.528 \\
Universidad de Costa Rica & 111.888 & .940 & 101.156 \\
Universidad de Panamá & 105.198 & 1.818 & 110.045 \\
Universidad San Martín (Colombia) & 100.999 & 1.228 & 101.633 \\
\hline
\end{tabular}

Table 2. Results of the comparison between the means of empathic orientation between different universities studied.

\begin{tabular}{|c|c|c|c|c|c|}
\hline \multirow{2}{*}{ Dental University } & \multirow{2}{*}{$\mathrm{N}$} & \multicolumn{4}{|c|}{ Subset } \\
\hline & & 1 & 2 & 3 & 4 \\
\hline Universidad de Magdalena & 173 & 92.48 & & & \\
\hline Universidad Metropolitana & 154 & & 99.41 & & \\
\hline Universidad San Martín & 168 & & 100.92 & & \\
\hline Universidad Central del Este & 239 & & 101.26 & & \\
\hline Universidad Latina de Panamá & 92 & & & 104.55 & \\
\hline ULACIT de Costa Rica ${ }^{*}$ & 225 & & & 105.49 & \\
\hline Universidad de Cartagena & 360 & & & 105.99 & \\
\hline Universidad de Panamá & 133 & & & 107.67 & \\
\hline Universidad de Costa Rica & 290 & & & & 111.88 \\
\hline Sig. & & 1.000 & 0.255 & 0.062 & 1.000 \\
\hline
\end{tabular}

${ }^{*}$ In the case of ULACIT Costa Rica, being a 4-year program, students will be distributed in 5 groups, according to school cycles.

Table 3. Results of the comparison of means between courses by Duncan’s test.

\begin{tabular}{cccc}
\hline Course & $\mathrm{N}$ & \multicolumn{1}{c}{ Subset } & \\
\cline { 3 - 3 } & & 99.62 & \\
First & 377 & & 104.08 \\
Second & 439 & & 105.10 \\
Fourth & 323 & & 105.30 \\
Fifth & 330 & & 106.28 \\
Third & 365 & 1.000 & 0.057 \\
Sig. & & & \\
\hline
\end{tabular}

universities compared differ. $\mathrm{X}^{2}$ tests, associated with the contrasts of the discriminant functions were highly significant $(p<0.0005)$ and fluctuated between 884.263 and 31.92 ; all of which show that the unexplained va the presence of different populations. Something similar occurs when comparing the data of the populations riance between the matrices is higher than the explained variance within these matrices, and in most cases are in 
Table 4. Results for the estimation of means of empathic orientation. Standard error and Confidence Intervals for each level of combination of the factors University and Course.

\begin{tabular}{|c|c|c|c|c|c|}
\hline \multirow{2}{*}{ Dental University } & \multirow{2}{*}{ Course } & \multirow{2}{*}{ Median } & \multirow{2}{*}{ Standard Error } & \multicolumn{2}{|c|}{ Confidence Interval of 95\% } \\
\hline & & & & Lower Limit & Upper Limit \\
\hline \multirow{5}{*}{ Universidad Latina de Panamá } & First & 100,833 & 5450 & 90,144 & 111,522 \\
\hline & Second & 101,806 & 5578 & 90,865 & 112,746 \\
\hline & Third & 102,056 & 7331 & 87,677 & 116,434 \\
\hline & Fourth & 98,769 & 3345 & 92,208 & 105,330 \\
\hline & Fifth & 109,722 & 2814 & 104,202 & 115,242 \\
\hline \multirow{5}{*}{ Universidad de Cartagena } & First & 100,618 & 1593 & 97,494 & 103,743 \\
\hline & Second & 106,634 & 1561 & 103,572 & 109,696 \\
\hline & Third & 107,509 & 2044 & 103,499 & 111,518 \\
\hline & Fourth & 105,146 & 1828 & 101,561 & 108,732 \\
\hline & Fifth & 107,715 & 1804 & 104,178 & 111,253 \\
\hline \multirow{5}{*}{ Universidad de Magdalena } & First & 92,977 & 2323 & 88,421 & 97,533 \\
\hline & Second & 98,272 & 2611 & 93,151 & 103,394 \\
\hline & Third & 98,100 & 2421 & 93,352 & 102,849 \\
\hline & Fourth & 88,881 & 2543 & 83,894 & 93,868 \\
\hline & Fifth & 84,220 & 2368 & 79,576 & 88,864 \\
\hline \multirow{5}{*}{ Universidad Metropolitana } & First & 97,615 & 2799 & 92,126 & 103,105 \\
\hline & Second & 98,023 & 2314 & 93,485 & 102,561 \\
\hline & Third & 100,089 & 2298 & 95,582 & 104,596 \\
\hline & Fourth & 95,185 & 2833 & 89,629 & 100,740 \\
\hline & Fifth & 109,392 & 3316 & 102,889 & 115,895 \\
\hline \multirow{5}{*}{ Universidad Central del Este } & First & 93,043 & 2247 & 88,636 & 97,449 \\
\hline & Second & 97,783 & 1829 & 94,195 & 101,370 \\
\hline & Third & 105,474 & 1894 & 101,759 & 109,189 \\
\hline & Fourth & 105,050 & 2985 & 99,195 & 110,905 \\
\hline & Fifth & 107,272 & 3234 & 100,930 & 113,614 \\
\hline \multirow{5}{*}{ ULACIT de Costa Rica } & First & 98,291 & 2515 & 93,358 & 103,224 \\
\hline & Second & 103,847 & 2130 & 99,669 & 108,025 \\
\hline & Third & 102,063 & 3474 & 95,249 & 108,877 \\
\hline & Fourth & 105,188 & 2436 & 100,410 & 109,966 \\
\hline & Fifth & 107,951 & 2423 & 103,199 & 112,703 \\
\hline
\end{tabular}




\begin{tabular}{|c|c|c|c|c|c|}
\hline \multicolumn{6}{|l|}{ Continued } \\
\hline & First & 107,463 & 2209 & 103,130 & 111,796 \\
\hline & Second & 109,383 & 1772 & 105,908 & 112,859 \\
\hline \multirow[t]{5}{*}{ Universidad de Costa Rica } & Third & 109,290 & 1846 & 105,669 & 112,911 \\
\hline & Fourth & 116,570 & 2382 & 111,899 & 121,242 \\
\hline & Fifth & 116,733 & 2233 & 112,354 & 121,113 \\
\hline & First & 106,899 & 2885 & 101,241 & 112,557 \\
\hline & Second & 106,795 & 3368 & 100,191 & 113,400 \\
\hline \multirow[t]{5}{*}{ Universidad de Panamá } & Third & 110,926 & 3965 & 103,149 & 118,704 \\
\hline & Fourth & 100,317 & 4080 & 92,315 & 108,319 \\
\hline & Fifth & 101,050 & 5527 & 90,209 & 111,891 \\
\hline & First & 97,038 & 2424 & 92,285 & 101,792 \\
\hline & Second & 99,625 & 2764 & 94,205 & 105,045 \\
\hline \multirow[t]{3}{*}{ Universidad San Martín } & Third & 99,222 & 3761 & 91,846 & 106,598 \\
\hline & Fourth & 112,655 & 2310 & 108,125 & 117,185 \\
\hline & Fifth & 96,455 & 2177 & 92,185 & 100,724 \\
\hline
\end{tabular}

formed by the interaction between the factors "Universities * Courses". The value of the Box M statistic (15553.48) was highly significant ( $p<0.005$ ); also indicating that the covariance matrices between populations, resulting from the combinations between the University and Course factors, differ.

\section{Discussion}

The results observed in the statisticians estimate for the variables of empathic orientation, comparing averages of this variable and the resulting matrix values and comparing these estimates between dental schools studied in Colombia, Panama, Costa Rica and Dominican Republic, allow the following generalizations: a) there are differences between dental schools of the universities studied; b) There are differences between courses, c) females have higher levels empathic orientation then males; d) interactions between factors (University and Course) were observed and, therefore, differences between populations derived from a combination at both levels; e) the existence of a coefficient of determination $\left(\mathrm{R}^{2}\right)$ relatively low and observation of a unexplained variance could be the expression of unknown factors or those not considered in this study and that they are influencing the variable factors of the level of empathy.

The variability of results observed in other studies, in which empathy levels were studied within each University or Faculty [11] [13]-[16] [27]-[38], allowed different findings. These differences are expressed in the factors studied, considering the course and gender. In some populations women were more empathic than men and in others the opposite occurred or simply there were no differences between genders. In the course factor, in some of the student populations, increasing with the elapsed academic years, in others it decreased and others remained stable. Besides the differences within these populations, we have found that they also occur among populations of students of the same career; possibley meaning, differences exist between schools within a country and between schools from different countries. One possible explanation for this variability is that the structure of each component of empathy depends on the influence of factors other than those of the other component. At the same time, empathy itself depends on the interaction between these components. Therefore, it is hypothetically possible to induce what is actually measured, with the applied scale, is the result of a complex process consisting in structuring and interaction of the components of empathy, a process that occurs in the context of another dimension: ontogenetic. As a consequence, the explanation of the variability between populations of students in relation to empathy is a complex problem [5]. The theory of mind and mirror neurons [39]-[46] can try to explain the processes occurring within the mind and there is empirical evidence to support it, but does not explain 
the entire process of formation of empathy. In this regard, the development process of the anatomical, psychological and neural basis of a subject, the way these are constructed and interact, are subjected to the action of external factors that act on the dialectical process [5]. As a result of the complex action of these factors, the way to integrate cognitive and affective components of empathy should be different among individuals, but also among populations, as these populations may have different economic standards and conditions, cultural, moral, educational, among others [1] [5]; which, can also differentially influence the building process of empathy. Therefore, the differences cannot be explained in this work; at best, be apprehended and a limitation of this study, which opens the doors to the need for further research to answer the question: What are all the factors responsible for these differences and how exactly do these modulate the process of the formation of empathy?

Current knowledge about empathy allows us to a firm that the formation of this construct in dentists (and in all professions in the area of health) is part of the responsibility of the universities [5] and, in this sense, some authors suggest that empathy can be learned [47] [48]. Therefore, the university has the task of studying the action of concrete practices that are possible to perform in order to raise levels of empathy in students, considering two aspects: a) that students who come to universities already have some empathic structure obtained by a previous experience of life and $b$ ) that the teaching of empathy in higher education (and in all educational systems) cannot be assumed with mechanistic conceptions. However, this work has restrictions which can be summarized as: a) the design used is cross-sectional and longitudinal study is needed to confirm whether these observed facts are maintained over time or vary with him and b) is necessary to study factors that could explain the behavior of the observed levels of empathy.

\section{Conclusion}

In accordance with the objective of this work, it was established that there was variability among student populations composed of dental schools in the same country and between schools from different countries. These differences could be empirical evidence of social and cultural factors that shaped empathy levels of a population and constituted a working hypothese for the future to clarify why this phenomenon occurred.

\section{Competing Interests}

The authors declare that they have no competing interests.

\section{Financing}

Research funded by the authors.

\section{References}

[1] Hojat, M., Gonella, J.S., Nasca, T.J., Mangione, S., Vergare, M. and Magee, M. (2002) Physician Empathy: Definition, Components, Measurement and Relationship to Gender and Specialty. American Journal of Psychiatry, 159, 15631569. http://dx.doi.org/10.1176/appi.ajp.159.9.1563

[2] Morales, S. (2012) Study of Empathy Level and Achievement Motivation in Students of Dentistry in University of Concepcion. Revista Educación en Ciencias de la Salud, 9, 121-125.

[3] Bilbao, J., Alcócer, A., Salazar, G., Rivera, I., Zamorano, A. and Díaz-Narváez, V.P. (2013) Measurement of Empathetic Orientation in Dentistry Students of Fundación Universitaria San Martín. Puerto Colombia (Atlántico, Colombia). (Atlántico, Colombia). Salud Uninorte (Barranquilla), 29, 34-41.

[4] Kane, G.C., Gotto, J.L., Mangione, S., West, S. and Hojat, M. (2007) Jefferson Scale of Patient’s Perceptions Empathy: Preliminary Psychometric Data 2007. Croatian Medical Journal, 48, 81-86.

[5] Díaz-Narváez, V.P., Alonso, L.M., Caro, S.E., Silva, M.G., Arboleda, J., Bilbao, J.L. and Iglesias, J. (2014) Empathic Orientation among Medical Students from Three Universities in Barranquilla, Colombia and One University in the Dominican Republic. Archivos Argentinos de Pediatría, 112, 41-49.

[6] Stephenson, A., Higgs, R. and Sugarman, J. (2001) Teaching Professional Development in Medical Schools. The Lancet, 357, 867-870. http://dx.doi.org/10.1016/S0140-6736(00)04201-X

[7] Alcorta-Garza, A., González-Guerrero, J.F., Tavitas-Herrera, S.E., Rodríguez-Lara, F.J. and Hojat, M. (2005) Validation of the Scale of Empathy Medical Jefferson Medical Students in Mexico. Salud Mental, 28, 57-63.

[8] Hojat, M., Mangione, S., Kane, G.C. and Gonnella, J.S. (2005) Relationship between Scores of the Jefferson Scale of 
Physician Emphaty (JSPE) and the Interpersonal Reactivity Index (IRI). Medical Teacher, 27, 625-628. http://dx.doi.org/10.1080/01421590500069744

[9] Roh, M., Hahm, B., Lee, D. and Suh, D. (2010) Evaluation of Empathy among Korean Medical Students: A Cross-Seccional Study Using the Korean Version of the Jefferson Scale of Physician Empathy. Teaching and Learning in Medicine, 22, 167-171. http://dx.doi.org/10.1080/10401334.2010.488191

[10] Kataoka, H., Koide, N., Ochi, K., Hojat, M. and Gonnella, J. (2009) Measurement of Empathy among Japanese Medical Student. Psychometrics and Score Differences by Gender and Level of Medical Education. Academic Medicine, 84, 1192-1197. http://dx.doi.org/10.1097/ACM.0b013e3181b180d4

[11] Silva, M.G., Arboleda, J. and Díaz-Narváez, V.P. (2013) Empathic Orientation Dental Students from the Universidad Central Del Este. Odontoestomatología, 15, 24-33.

[12] Díaz-Narváez, V.P. (2009) Scientific Research Methodology and Biostatistics for Professionals and Students of Health Sciences. 2ed, RiL Editores, Santiago.

[13] Erazo, A.M., Alonso, L.M., Rivera, I., Zamorano, A. and Díaz-Narváez, V.P. (2012) Measuring Empathic Orientation Dental Students Barranquilla Metropolitan University (Colombia). Revista Salud Uninorte, 28, 354-363.

[14] Sánchez, L., Padilla, M., Rivera, I., Zamorano, A. and Díaz-Narváez, V.P. (2013) Evaluation of Empathetic Orientation in Odontology Students. Educación Médica Superior, 27, 216-225.

[15] Howard, M., Navarro, S., Rivera, I., Zamorano, A. and Díaz-Narváez, V.P. (2013) Measuring the Level of Empathic Orientation in the Student of the Faculty of Dentistry, University of Costa Rica. Revista Odovtos, 15, 21-26.

[16] Rivera, I., Arratia, R., Zamorano, A. and Díaz-Narváez, V.P. (2011) Evaluación del nivel de orientación empática en estu-diantes de Odontología. Salud Uninorte (Barranquilla, Colombia), 27, 63-72.

[17] Leyva, Y.E. (2011) A Review of the Construct Validity of Criterion-Referenced Tests. Perfiles Educativos, 33, 131154.

[18] Cervantes, V. (2005) Interpretations of Cronbach’s Alpha Coefficient. Avances en Medición, 3, 9-28.

[19] Oviedo, H.C. and Campo-Arias, A. (2005) An Approach to the Use of Cronbach's Alfa. Revista Colombiana de Psiquiatría, 34, 572-580.

[20] Streiner, D.L. (2003) Starting at the Beginning: An Introduction to Coefficient Alpha and Internal Consistency. Journal of Personality Assessment, 80, 99-103. http://dx.doi.org/10.1207/S15327752JPA8001_18

[21] Shapiro, S.S. and Wilk, M.B. (1965) An Analysis of Variance Test for Normality (Complete Samples). Biometrika, 52, 591-611. http://dx.doi.org/10.1093/biomet/52.3-4.591

[22] Hair, J.F., Anderson, R.E., Tatham, R.L. and Black, W.C. (2001) Multivariate Analysis. Prentice-Hall, Madrid.

[23] Frías, M.D., Llobell, J.P. and García, J. (2000) Size of Treatment Effect and Statistical Significance. Psicothema, 2, 236-240.

[24] Levy, J.P. and Varela, J. (2003) Multivariate Analysis for the Social Sciences. Pearson Prentice-Hall, Madrid, $249-257$.

[25] Visauta, B. (1998) Statistical Analysis with SPSS: Vol. II. McGraw-Hill, Madrid, 135-137.

[26] Palacios, S. (2007) Development and Validation of the Scale of Values Domains Television (DETV). Revista Investigación en Educación, 25, 403-420.

[27] Silva, H., Rivera, I., Zamorano, A. and Díaz-Narváez, V.P. (2013) Evaluation of Empathetic Orientation in Dentistry Students of Finis Terrae University in Santiago, Chile. Revista Clínica de Periodoncia, Implantología y Rehabilitación Oral, 6, 130-133.

[28] Carrasco, D., Bustos, A. and Díaz, V. (2012) Empathetic Orientation of Chilean Dental Students. Revista Estomatológica Herediana, 22, 145-151.

[29] Oviedo, M. (2011) Empathy Training of Students in the Faculty of Dentistry at the University of Carabobo. Universidad Autónoma de Madrid, 158.

http://biblioteca.universia.net/html bura/ficha/params/title/empatia-estudiantes-formacion-facultad-odontologia-univer sidad-carabobo/id/55311551.html

[30] Alonso, L.M., Caro, S.E., Erazo, A.M. and Díaz-Narváez, V.P. (2013) Evaluación de la orientación empática en estudiantes de medicina de la Universidad del Norte. Barranquilla (Colombia). Revista Salud Uninorte, 29, 22-33.

[31] Rojas-Serey, A.M., Castañeda-Barthelemiez, S. and Parraguez-Infiesta, R.A. (2009) Empathetic Orientation of the Physical Therapist’s Students from Two Schools of Chile. Educación Médica, 12, 103-109.

[32] Chen, D., Lew, R., Hershman, W. and Orlander, J. (2007) A Cross-Sectional Measurement of Medical Student Empathy. Journal of General Internal Medicine, 22, 1434-1438. http://dx.doi.org/10.1007/s11606-007-0298-X

[33] Bellini, L. and Shea, J. (2005) Mood Change and Empathy Decline Persist during Three Years of Internal Medicine Training. Academic Medicine, 80, 164-167. http://dx.doi.org/10.1097/00001888-200502000-00013 
[34] Chen, J., LaLopa, J. and Dang, D. (2008) Impact of Patient Empathy Modeling on Pharmacy Students Caring for the Underserved. American Journal of Pharmaceutical Education, 72, Article 40. http://dx.doi.org/10.5688/aj720240

[35] Nunes, P., Willians, S., Sa, B. and Stevenson, K. (2011) A Study of Emphaty Decline in Students from Five Health Disciplines during Their First Year of Training. International Journal of Medical Education, 2, 12-17. http://dx.doi.org/10.5116/ijme.4d47.ddb0

[36] Hojat, M., Vergare, M.J., Maxwell, K., Brainard, G., Herrine, S.K., Isenberg, G.A., Veloski, J. and Gonnella, J.S. (2009) The Devil Is in the Third Year: A Longitudinal Study of Erosion of Empathy in Medical School. Academic Medicine, 84, 1182-1191. http://dx.doi.org/10.1097/ACM.0b013e3181b17e55

[37] Sherman, J. and Cramer, A. (2005) Measurement of Changes in Empathy during Dental School. Journal of Dental Education, 69, 338-345.

[38] Beattie, A., Durham, J., Harvey, J., Steele, J. and McHanwell, S. (2012) Does Empathy Change in First-Year Dental Student? European Journal of Dental Education, 16, e111-e116. http://onlinelibrary.wiley.com/doi/10.1111/j.1600-0579.2011.00683.x/full

[39] Gutiérrez-Ventura, F., Quezada-Huerta, B., López-Pinedo, M., Méndez-Vergaray, J., Díaz-Narváez, V., Zamorano, A and Rivera, I. (2012) Measuring the Level of Empathic Perception of Students of the Faculty of Dentistry Robert Beltrán. Cayetano Heredia Peruvian University. Revista Estomatológica Herediana, 22, 91-99.

[40] Varela, T., Villalba, R.H., Gargantini, P., Quinteros, S., Villaba, S.B. and Díaz-Narváez, V.P. (2012) Levels of Empathic Orientation Dental Students at the Catholic University of Cordoba, Argentina (UCC). Claves de Odontología, 70, $15-22$.

[41] Rivera, I., Arratia, R., Zamorano, A. and Díaz-Narváez, V.P. (2011) Measurement of Empathetic Orientation in Dentistry Students. Revista Salud Uninorte, 27, 63-72.

[42] Garaigordobil, M. and García de Galdeano, P. (2006) Empathy in Children Aged 10 to 12 Years. Psicothema, 18, 180186.

[43] Rizzolatti, G., Fogassi, L. and Gallese, V. (2001) Neurophisiological Mechanisms Underlying the Understanding and Imitation of Action. Nature Reviews Neuroscience, 2, 661-670. http://dx.doi.org/10.1038/35090060

[44] García-García, E., González, J. and Maestú-Unturbe, F. (2011) Mirror Neurons and Theory of Mind in Explaining Empathy. Ansiedad y Estrés, 17, 265-279.

[45] Arán, V., López, M.B. and Richaud, M.C. (2012) Neuropsychological Approach to the Empathy Construct: Cognitive and Neuroanatomical Aspects. Cuadernos de Neuropsicología, 6, 63-83.

[46] Smith, A. (2006) Cognitive Empathy and Emotional Empathy in Human Behavior and Evolution. The Psychological Record, 56, 3-21.

[47] Almonte, C. and Montt, M.A. (2012) Child and Adolescent Psychopathology. $2^{\mathrm{a}}$ Ed, Mediterráneo, Santiago, 45-58.

[48] Schwartz, B. and Bohay, R. (2012) Can Patients Help Teach Professionalism and Empathy to Dental Students? Adding Patient Videos to a Lecture Course. Journal of Dental Education, 76, 174-184. 